\title{
Positive role of cell wall anchored proteinase PrtP in adhesion of lactococci
}

\author{
Olivier Habimana1,2, Carine Le Goff2,4, Vincent Juillard2, Marie- \\ Noëlle Bellon-Fontaine1, Girbe Buist ${ }^{3,5}$, Saulius Kulakauskas*2 and \\ Romain Briandet ${ }^{1}$
}

\begin{abstract}
Address: ${ }^{1}$ Unité Mixte de Recherche en Bioadhésion et Hygiène des Matériaux, INRA-ENSIA, 91744 Massy cedex, France, ${ }^{2}$ Unité Bactéries Lactiques et pathogènes Opportunistes, Institut National de la Recherche Agronomique, Domaine de Vilvert, 78352 Jouy-en-Josas cedex, France,

${ }^{3}$ Department of Molecular Genetics, Groningen Biomolecular Sciences and Biotechnology institute, University of Groningen, Kerklaan 30, 9751 NN Haren, The Netherlands, ${ }^{4}$ U781, INSERM, Hôpital Necker enfants malades, Tour Lavoisier, 149 rue de Sèvres, 75015 Paris cedex, France and ${ }^{5}$ Department of Medical Microbiology, University Medical Center Groningen and University of Groningen, Hanzeplein 1, P.O. Box 30001 , 9700 RB Groningen, the Netherlands
\end{abstract}

Email: Olivier Habimana - Olivier.Habimana@jouy.inra.fr; Carine Le Goff - clegoff@necker.fr; Vincent Juillard - Vincent.Juillard@jouy.inra.fr; Marie-Noëlle Bellon-Fontaine - mnbellon@jouy.inra.fr; Girbe Buist - g.buist@med.umcg.nl;

Saulius Kulakauskas* - saulius.kulakauskas@jouy.inra.fr; Romain Briandet - Romain.Briandet@jouy.inra.fr

* Corresponding author

Published: 2 May 2007

BMC Microbiology 2007, 7:36 doi:10.1 |86/147|-2/80-7-36
Received: 4 September 2006

Accepted: 2 May 2007

This article is available from: http://www.biomedcentral.com/I47I-2/80/7/36

(c) 2007 Habimana et al; licensee BioMed Central Ltd.

This is an Open Access article distributed under the terms of the Creative Commons Attribution License (http://creativecommons.org/licenses/by/2.0), which permits unrestricted use, distribution, and reproduction in any medium, provided the original work is properly cited.

\begin{abstract}
Background: The first step in biofilm formation is bacterial attachment to solid surfaces, which is dependent on the cell surface physico-chemical properties. Cell wall anchored proteins (CWAP) are among the known adhesins that confer the adhesive properties to pathogenic Gram-positive bacteria. To investigate the role of CWAP of non-pathogen Gram-positive bacteria in the initial steps of biofilm formation, we evaluated the physico-chemical properties and adhesion to solid surfaces of Lactococcus lactis. To be able to grow in milk this dairy bacterium expresses a cell wall anchored proteinase PrtP for breakdown of milk caseins.

Results: The influence of the anchored cell wall proteinase PrtP on microbial surface physicochemical properties, and consequently on adhesion, was evaluated using lactococci carrying different alleles of prtP. The presence of cell wall anchored proteinase on the surface of lactococcal cells resulted in an increased affinity to solvents with different physico-chemical properties (apolar and Lewis acid-base solvents). These properties were observed regardless of whether the PrtP variant was biologically active or not, and were not observed in strains without PrtP. Anchored PrtP displayed a significant increase in cell adhesion to solid glass and tetrafluoroethylene surfaces.

Conclusion: Obtained results indicate that exposure of an anchored cell wall proteinase PrtP, and not its proteolytic activity, is responsible for greater cell hydrophobicity and adhesion. The increased bacterial affinity to polar and apolar solvents indicated that exposure of PrtP on lactococcal cell surface could enhance the capacity to exchange attractive van der Waals interactions, and consequently increase their adhesion to different types of solid surfaces and solvents.
\end{abstract}




\section{Background}

In natural aquatic populations, bacteria often live in biofilms, which may be described as matrix-enclosed bacterial communities attached to a substratum [1,2]. Biofilm formation allows bacteria to survive in environments that would be lethal for their planktonic counterparts $[3,4]$. Key event in biofilm formation is bacterial adhesion on a surface that depends on factors such as preconditioning of the support by macromolecules and the physico-chemical interactions between the bacterial cells and the substratum $[5,6]$.

In the dairy industry, biofilms usually occur on surfaces that are in contact with fluids, and may be a source of bacterial contamination leading to technological and economical problems [7-9]. Nevertheless, protective biofilm formation on food industry workshop surfaces can also be beneficial because their presence may effectively modify the physico-chemical properties of substrates and as such, reduce adhesion of the undesirable planktonic microorganisms [10,11]. Furthermore, multiplication of the undesirable organism may be inhibited by nutrient competition or by synthesis of antagonistic compounds such as acids, bacteriocins, or surfactants $[12,13]$. In recent years, biofilms of lactic acid bacteria have received considerable attention for their potential use in the settlement of a competitive flora $[14,15]$. Lactococcus lactis is the most frequently used dairy bacterium for fermentation and preservation purposes. Lactococci do not present any detrimental effect on the sensory properties of processed foods, making them a suitable candidate for the creation of protective biofilms.

Various studies have demonstrated that bioadhesion depends mainly on combination of surface physicochemical properties (such as Lewis acid-base character, capacity to exchange attractive van der Waals interactions, and global surface charge) of both the cell and the solid substratum $[5,16,17]$. Concerning bacterial surfaces, these properties depend on molecular cell surface composition. It was shown that the L. lactis ssp. lactis LMG9452 surface is composed mainly of proteins and polysaccharides and has a hydrophilic character [18]. However, it is still unclear as to which lactococcal cell surface molecules influence particular physico-chemical properties and adhesion.

Cell wall anchored proteins (CWAP) are among the known bacterial cell surface components having adhesive properties[19]. This group includes adhesins or proteins influencing coaggregation, e.g., fibronectin and collagen binding proteins of Staphylococcus aureus, S. schleiferi $[20,21]$, or glucan binding protein of Streptococcus mutans [19]. Concerning L. lactis, three surface proteins were attributed to the same group of CWAP: i) the chromo- somally-encoded sex factor CluA [22], ii) the plasmidencoded proteinase NisP [23], and iii) the plasmidencoded cell serine proteinase PrtP (also called lactocepin [24], which initiates proteolytic degradation of milk casein [25]). Like other CWAP, the lactococcal PrtP proteinases are characterized by a signal sequence at the N-terminus that is cleaved during secretion across the membrane; and a LPXTG sorting motif followed by a hydrophobic membrane-spanning region and a positively charged tail at the C-terminus [25]. After protein translocation through the membrane, the sortase enzyme mediates cleavage of LPXTG such that the threonine carboxyl group is linked to the cross-bridges in the peptidoglycan layer [26]. Deletion of the N-terminal end containing the LPXTG motif results in complete secretion of the truncated proteinase [27]. Fusion of the C-terminal LPXTG containing domain of PrtP with several reporter proteins resulted in the surface exposure of the fusion proteins $[28,29]$.

The role of bacterial cell wall anchored proteins in adhesion was studied mainly in connection with their possible roles in virulence [21]. Previous studies addressed specific binding to host cell components like platelets, albumin, fibrinonectin, or collagen $[20,21,30]$. However, the role of cell wall anchored proteins of non-pathogenic bacteria on cell surface physico-chemical properties and adhesion to inert surfaces has not been examined.

The aim of this work was to evaluate the influence of the proteinase PrtP on hydrophobic/hydrophilic characteristics, Lewis acid-base properties, electrical charge and adhesive capacity of lactococci.

\section{Results \\ Determination of the hydrophobic/hydrophilic and Lewis- acid base characters}

We used derivatives of $L$. lactis ssp. cremoris strain

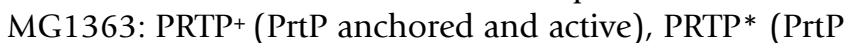
anchored and inactive) and PRTP- (MG1363 carrying vector plasmid pGKV2 without prtP gene) as control strain. The strain MG1363 does not express other surface exposed proteinases although several membrane and cytoplasmic proteases are present [31]. As previously was shown that expression of various proteinase derivatives from the same promoter resulted in the same amount of proteinase [32], it was assumed that the proteinase expression in PRTP $^{+}$and PRTP* strains was identical.

The MATS kinetic experiment was used to determine the dynamic interaction of lactococci carrying different alleles of prtP gene (PRTP-, PRTP+ and PRTP*) with polar (chloroform and ethyl acetate) and apolar (hexadecane and decane) solvents (Fig. 1). To extract the maximal affinity to solvents $\left(A_{\max }\right)$ and the initial slope $\left(A_{\max } \cdot k\right)$ values, the 
experimental data presented in Fig. 1 were fitted using the following exponential expression: $A(t)=A_{\max } \cdot\left[1-e^{(-k \cdot t)}\right]$

where $A(t)$ is the affinity as a function of time, $A_{\max }$ the maximal affinity; $A_{\max } \cdot k$, the initial slope and $t$, the time in seconds. The maximal affinity and the initial slope values are presented in Table 1.

For cells expressing anchored proteinase PRTP* and PRTP $^{+}$a maximum affinity was reached between 20 to 40 second interaction with mono-polar solvents (chloroform and ethyl acetate), while the maximum affinity to apolar solvents (hexadecane, decane) was attained after a period of time superior to 60 seconds. PRTP* had higher initial slope (12.1) of affinity to ethyl acetate compared to $\mathrm{PRTP}^{+}$(3. 2). The difference between these two strains was slightly less pronounced in case of chloroform: 10.5 for PRTP* and 6.6 for PRTP $^{+}$(Table 1).

Our results showed that control strain PRTP- exhibited very low affinity for all four solvents (maximal affinity $<20 \%$ ) independently of their different physico-chemical properties (whether apolar, Lewis-acid or Lewis-base). Low affinity for apolar solvents (i.e. $A_{\max }$ for hexadecane
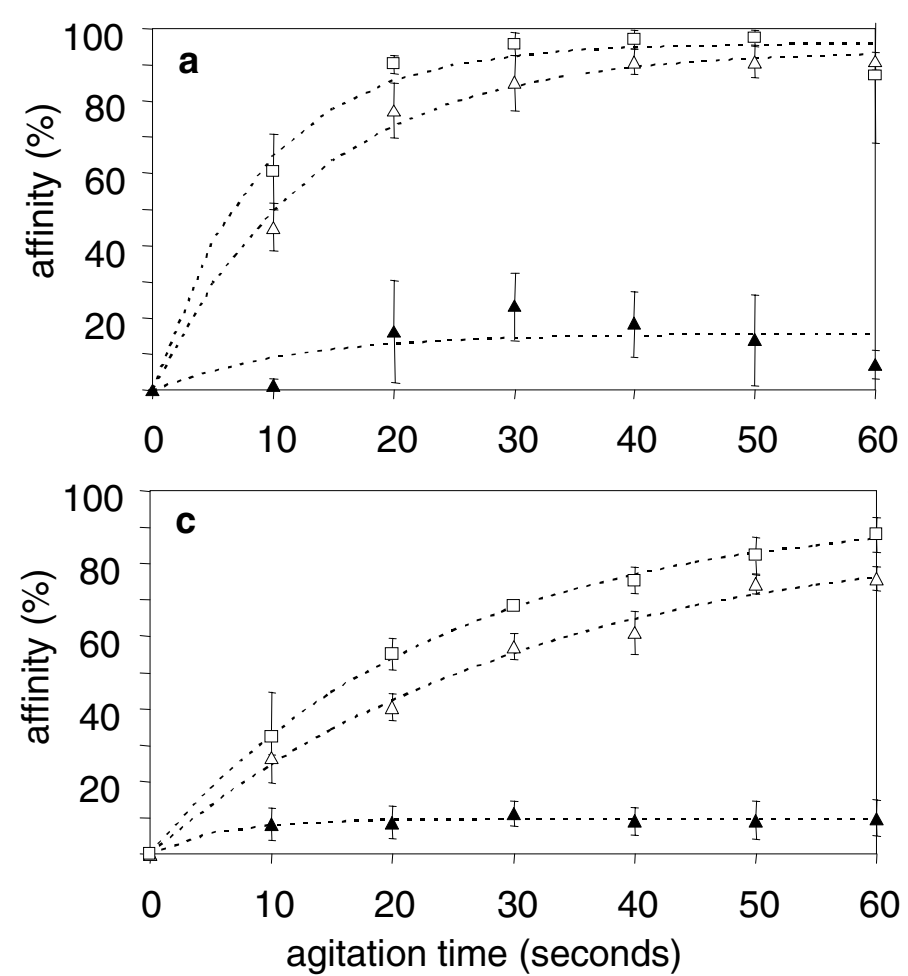

and decane was less than 10\%), indicated the lack of hydrophobic properties of PRTP- control strain (Table 1).

The hydrophobic character of the two other strains expressing anchored proteinase (PRTP+ and PRTP*) was different: they both exhibited higher affinity to all solvents $(\mathrm{P}<0.05$; Fig. 1$)$. The higher affinity for all solvents was observed in strain PRTP*, encoding anchored inactive PrtP. The presence of anchored proteinase generally resulted in an increase of bacterial affinity for apolar solvents hexadecane and decane, since $A_{\max }$ values comprised in the range $89-95 \%$ for PRTP+ and PRTP* ${ }^{*}$ in comparison to values of less than $10 \%$ for control strain PRTP- $(\mathrm{P}<$ 0.05; Table 1). This suggests that anchored PrtP, active or not, markedly mediated the increase of cell hydrophobicity.

\section{Evaluation of cell wall electrical charge}

The same L. lactis strains, carrying different prtP alleles were used to evaluate global cell surface charge. Electrophoretic mobility (EM) of three bacterial strains (PRTP-, PRTP+, and PRTP*) at $^{*} \mathrm{H}$ values ranging from 2 to 7 are presented in Fig. 2. We observed that all strains were highly electronegative and an isoelectric point could not be determined in the $\mathrm{pH}$ range explored. In all cases the
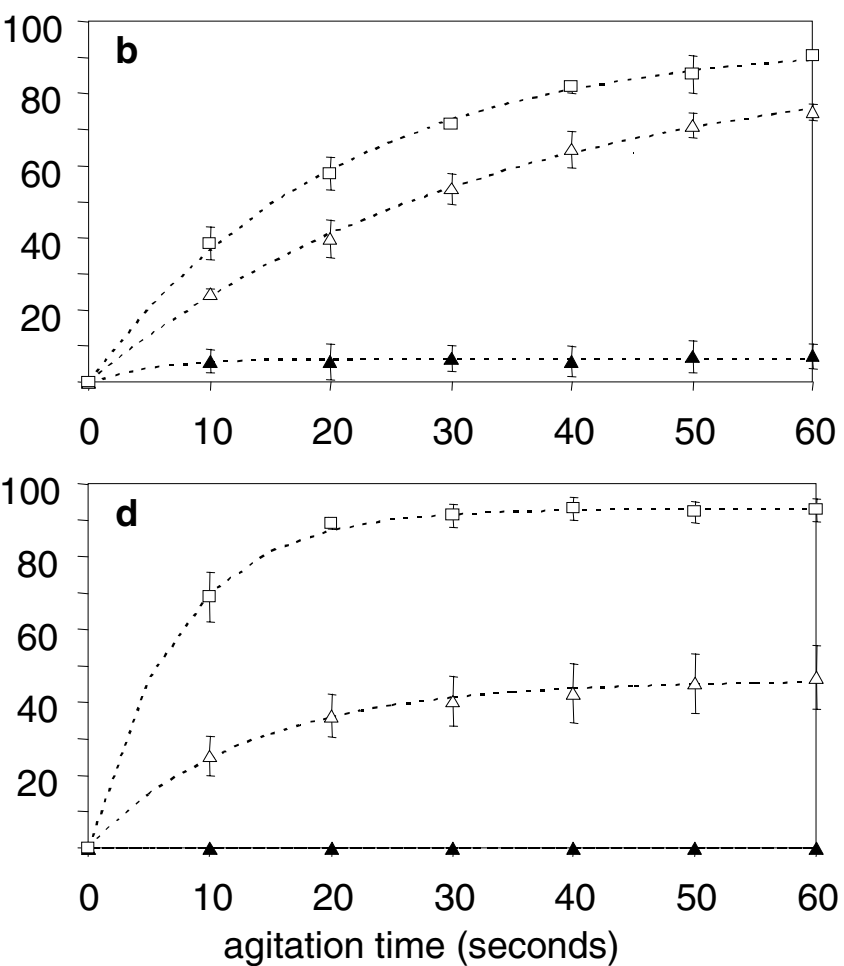

Figure I

Affinities of MG I363 derivatives carrying different prtP alleles to four solvents used in kinetic MATS analysis: chloroform (a), hexadecane (b), decane (c) and ethyl acetate (d). Open squares - PRTP*, open triangles - PRTP+, closed triangles - PRTP-. 
Table I: The maximal affinity to chloroform, hexadecane, decane and ethyl acetate and initial slope values of MGI363 carrying different prtP alleles

\begin{tabular}{cccccc}
\hline & Strain & Chloroform & Hexadecane & Decane & Ethyl acetate \\
\hline \multirow{2}{*}{$A_{\max }$} & PRTP & 15.6 & 6.5 & 9.6 & 0.0 \\
& PRTP + & 94.0 & 90.2 & 89.5 & 95.9 \\
& PRTP * & 95.8 & 94.0 & 94.1 & 93.1 \\
\hline \multirow{2}{*}{$A_{\text {max }} \cdot k$} & PRTP & 1.2 & 1.2 & 1.6 & 0.0 \\
& PRTP + & 6.6 & 2.7 & 2.8 & 3.2 \\
& PRTP * & 10.5 & 3.8 & 4.0 & 12.1 \\
\hline
\end{tabular}

The maximal affinity and initial slope values were extracted from experimental data presented in Fig. I.

EM values reached their minimum at $\mathrm{pH}$ values of 4 , as was observed in previous studies with different lactic acid producing bacteria $[18,33]$. At $\mathrm{pH}$ range exceeding 3 the presence of anchored proteinase significantly reduced the negative charge of microbial cells $(P<0.05$, Fig. 2$)$. This effect was maximal for cells expressing anchored active proteinase: $\mathrm{EM}^{\mathrm{N}}$ values of $\mathrm{PRTP}^{+}$were higher than $-2 \times 10^{-8}$ $\mathrm{m}^{2} \mathrm{~V}^{-1} \mathrm{~s}^{-1}$, in comparison to less that $-3 \times 10^{-8} \mathrm{~m}^{2} \mathrm{~V}^{-1} \mathrm{~s}^{-1}$ for control strain PRTP- (Fig. 2).

\section{Evaluation of adhesion to solid surfaces}

We used glass and PTFE to study the influence of anchored PrtP on lactococcal adhesion to solid surfaces. Physicochemical properties of these two solid substrates were evaluated by contact angle measurements. The van der Waals $\left(\gamma^{\mathrm{LW}}\right)$, Lewis-base $(\gamma)$ and Lewis-acceptor $\left(\gamma^{+}\right)$components of the surface tension $\left(\gamma^{S}\right)$ of glass and PTFE are presented in Table 2 . In agreement with previously published data [6], glass exhibited a strong hydrophilic char$\operatorname{acter}\left(\Theta_{\text {water }}=10^{\circ}\right)$. The hydrophilic glass nature is mainly due to its Lewis base character $\left(\gamma=55 \mathrm{~mJ} \cdot \mathrm{m}^{2}\right)$. This test indicated that PTFE was almost apolar $\left(\gamma^{\mathrm{AB}} \sim 0\right)$ and exhibited very low van der Waals character $\left(\gamma^{\mathrm{LW}}=15\right)$, indicating low interacting capacity.

Adhesion to glass and PTFE of lactococci expressing different prtP alleles was examined in two concentration $\mathrm{NaCl}$, $1.5 \mathrm{mM}$ and $150 \mathrm{mM}$. We observed a statistically significant increase $(\mathrm{P}<0.05)$ of adhesion for strains expressing anchored PrtP, independently of their proteolytic activity and the surface $\left(3-6\right.$ fold for $\mathrm{PRTP}^{+}$and $8-10$ fold for PRTP*; Table 3). This increase was significantly $(\mathrm{P}<0.05)$ higher in $150 \mathrm{mM} \mathrm{NaCl}$ solution.

\section{Discussion}

The aim of this work was to study the involvement of the cell wall proteinase PrtP on physico-chemical mechanisms of adhesion of $L$. lactis to solid surfaces. In our experimental conditions, the presence of CWAP PrtP, active or inactivated, on the cell surface modified the physico-chemical surface properties as well as microbial adhesion to hydrophobic (PTFE) or hydrophilic (glass) surfaces (proteinase is active in PRTP $^{+}$and inactive in PRTP*). Efficient adhesion of the strain expressing inactivated cell surface-anchored PrtP indicated that the presence of PrtP on the cell surface, and not its proteolytic activity, is important in this phenomena.

We ruled out possible effects of vector itself on adhesion: the physico-chemical properties and adhesion of MG1363 with or without vector pGKV2 [34], used to clone prtP, were essentially the same (results not shown). Proteolytic activity of cloned PrtP proteinases used in this work is comparable to that of a wild type strain, suggesting that their expression and anchoring could be also comparable [35]. This allows us to suggest that adhesion via PrtP may also occur in natural strains. Moreover, it has been shown that PrtP expression in milk is more efficient than in M17 medium, used in this study [31]. Therefore we can expect that in dairy environment the effect of PrtP on cell surface properties would be even more pronounced.

The adhesive behavior of strains bearing surface-anchored PrtP could be explained by changes in cell surface physicochemical properties. Electrophoretic mobility measurements revealed that the presence of proteinase on the lactococcal cell surface is correlated with a reduced global negative charge. The high negative charge and the absence of isoelectric point in the $\mathrm{pH}$ range we examined could be linked to the presence of (lipo)teichoic acid in the cell wall that contains many phosphates groups with a $\mathrm{pKa}$ of around 2 [18]. The clear reduction of negative charge in cells displaying PrtP may be explained by an increase of the N/P (protein/phosphate) ratio of the bacterial cell wall [18]. The ability of PrtP to bind cations such as $\mathrm{Ca}^{++}$ may also have an influence on global surface charge [36].

We observed more efficient adhesion of PRTP* strain to solid (glass and PTFE) surfaces as compared to PRTP+ strain ( $\mathrm{p}<0.05$; Table 3 ). Moreover, we observed the difference in PRTP*adhesion between high (150 mM) and low (1.5 mM) ionic strength conditions. Since both bacterial (Fig. 2) and glass or PTFE [37] surfaces are negatively 


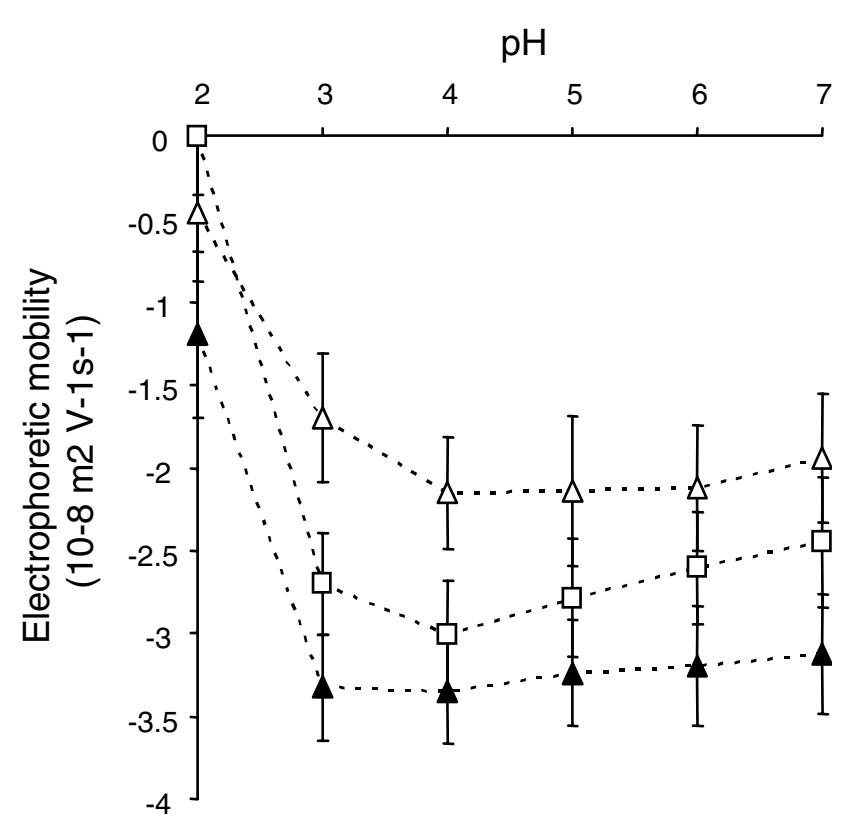

Figure 2

Electrophoretic mobility of MG I 363 derivatives carrying different prtP alleles in $1.5 \mathrm{mM} \mathrm{NaCl}$ solution at pH 2 to 7. Open squares - PRTP*, Open triangles - PRTP+, closed triangles - PRTP-.

charged, this could be explained by stronger electrostatic repulsion in low salt concentration. However, the differences in adhesion between PRTP- and PRTP* strains were more expressed in high salt concentration, the conditions where repulsive electrostatic interactions are strongly diminished ([6], Table 3). We therefore suggest that electrostatic interactions do not play a predominant role in PrtP mediated adhesion.

The MATS test showed that strains bearing anchored PrtP had increased affinity for all solvents tested, independently of their nature, i.e., polar, less hydrophobic (ethyl acetate and chloroform) or apolar, more hydrophobic (decane and hexadecane). Furthermore, adhesion of strain bearing anchored PrtP increased regardless of whether the substrate was PTFE, which is apolar and hydrophobic, or glass, which is polar and hydrophilic [38]. Based on these results, we hypothesize that the presence of PrtP increases the capacity of the cell to exchange attractive van der Waals interactions; these interactions would increase bioadhesion of lactococci displaying anchored PrtP to different types of surfaces (e.g., inert, polar or apolar, or organic).

The affinity of inactive PRTP* to solvents and to solid surfaces was higher in comparison with its active counterpart PRTP $^{+}$. This effect could be explained by degradation of main lactococcal autolysin AcmA by PRTP+ [39]. AcmA activity was reported to increase significantly bacterial adhesion [40,41]. Degradation of AcmA by PrtP could diminish its activity and consequently adhesive properties. Alternatively, the greater affinity of inactive PrtP carrying strains to solvents and to solid surfaces may be explained by the absence of self-cleavage. Such self-cleavage is characteristic to an active proteinase and consequently could result in lower number of molecules present on cell surface [34].

We observed a very low affinity of lactococci to apolar solvents, consistent with previous results using $L$. lactis strain LMG9452 [18]. The presence of anchored proteinase thus increased strain hydrophobicity. The hydrophobic character was reported as feature of a number of Gram-positive bacteria which possess cell wall anchored proteins $[42,43]$. The increase of hydrophobicity by cell wall anchored proteins may be a common property of Grampositive bacteria. Nevertheless, other factors (like polysaccharides) could mask this effect. For example, in the case of hydrophilic L. lactis strain LMG9452, the surface is dominated by polysaccharides rather than proteins [18].

Surface proteins other than those that are anchored via an LPXTG motif may affect bioadhesion. For example, autolysins of Staphylococcus epidermidis were recently shown to affect primary attachment to solid surfaces, and the autolysin of Listeria monocytogenes contributes to adhesion to eucaryotic cells $[44,45]$. Presence of PrtP on the lactococcal cell surface increases adhesion to glass and to PTFE about 10 fold. The ability of a single protein to change adhesion to this extent may also indicate that there are few other proteins present on the lactococcal cell surface or that these proteins do not affect adhesion. Two confirmed lactococcal proteins with cell wall anchor domains are the sex factor protein CluA [22], and plasmid-encoded NisP [23], which is not present in MG1363.

Table 2: Surface tension components of glass and PTFE

\begin{tabular}{ccccccccc}
\hline & $\theta_{\mathbf{W}}$ & $\theta_{\mathbf{F}}$ & $\theta_{\mathbf{D}}$ & $\gamma^{\mathbf{L W}}$ & $\gamma$ & $\gamma^{+}$ & $\gamma^{\mathbf{A B}}$ & $\gamma^{\mathbf{S}}$ \\
\hline Glass & $10^{\circ}$ & $17^{\circ}$ & $61^{\circ}$ & 28 & 55 & 4 & 30 & 58 \\
PTFE & $109^{\circ}$ & $95^{\circ}$ & $83^{\circ}$ & 15 & 1.5 & 0 & 0 & 15
\end{tabular}

Contact angles measured on glass and PTFE with water $\left(\theta_{\mathrm{w})}\right.$, formamide $\left(\theta_{\mathrm{F})}\right.$ and diiodomethane $\left(\theta_{\mathrm{D}}\right)$; and derived Van der Waals, $\left(\gamma^{\mathrm{LW}}\right)$, electrondonor $(\gamma)$, electron-acceptor $\left(\gamma^{+}\right)$and polar $\left(\gamma^{\mathbf{A B}}\right)$ components of the materials surface energy $\left(\gamma^{\mathbf{S}}\right)$ expressed in $\mathrm{mJ} \cdot \mathrm{m}^{-2}$. 
Table 3: Adhesion to glass and PTFE surface by MG 1363 carrying different prtP alleles in two $\mathrm{NaCl}$ concentrations.

\begin{tabular}{lcccc}
\hline Strain & \multicolumn{3}{c}{ Percentage of surface coverage on: } \\
\cline { 2 - 5 } & \multicolumn{3}{c}{ Glass } & PTFE \\
\cline { 2 - 5 } & $150 \mathrm{mM} \mathrm{NaCl}$ & $1.5 \mathrm{mM} \mathrm{NaCl}$ & $150 \mathrm{mM} \mathrm{NaCl}$ & $1.5 \mathrm{mM} \mathrm{NaCl}$ \\
\hline PRTP- & $5.0 \pm 1.9$ & $4.5 \pm 1.5$ & $4.7 \pm 2.9$ & $3.5 \pm 1.7$ \\
PRTP + & $33.5 \pm 8.4$ & $18.4 \pm 4.2$ & $12.7 \pm 3.4$ & $13.6 \pm 3.5$ \\
PRTP* & $49.7 \pm 6.8$ & $35.8 \pm 6.9$ & $39.0 \pm 7.5$ & $22.7 \pm 4.1$ \\
\hline
\end{tabular}

The CluA dependent cell aggregation phenotype is reportedly poorly expressed unless a co-integrate is formed between the sex factor and a lactose plasmid [22], so we consider it unlikely that CluA is a significant adhesion factor in our experimental system.

\section{Conclusion}

We have shown that the cell wall anchored PrtP proteinase, in addition to its role in milk casein degradation, is responsible for greater cell hydrophobicity and adhesion to solid surfaces. An increase of adhesion to polar and apolar solid surfaces and solvents indicates that attractive van der Walls interactions may be responsible for PrtP mediated lactococcal adhesion. Obtained results indicate that PrtP, and not its proteolytic activity, are responsible for the changes of these cell surface physico-chemical properties. We suggest that PrtP or its derivatives can be used as a tool to construct strains with increased adhesion that form protective biofilms.

\section{Methods}

\section{Bacterial strains and growth conditions}

The Lactococcus lactis ssp. cremoris strain MG1363 [46] was used as host for three isogenic plasmids: pGKV2 [47]; strain carrying this plasmid called here PRTP-); pGKV552 (derivative of pGKV2, containing cloned prtPI gene [34]; strain carrying this plasmid is called here PRTP $^{+}$); and pGKV1552 (derivative of pGKV552, where PrtPI is inactivated by in-frame point mutation of Asp-30 to Asn-30 in a catalytic site [34], strain carrying this plasmid called here PRTP*). Plasmid pGKV2 contains the replication origin of the cryptic L. lactis WG2 plasmid pWV01 and the erythromycin and chloramphenicol resistance genes [47]. Bacteria were cultivated in M17 medium [48] supplemented with $5 \%$ of glucose at $30^{\circ} \mathrm{C}$. When needed, $5 \mu \mathrm{g} / \mathrm{ml}$ of erythromycin was added.

\section{MATS (Microbial adhesion to solvents)}

The method is based on comparing the affinity between microbial cells and a mono-polar or an apolar solvents [49]. The polar solvent can be an electron-acceptor or an electron-donor. The solvents used in this study were: chloroform (an electron-acceptor solvent), hexadecane (non- polar solvent), ethyl acetate (an electron-donor solvent) and decane (nonpolar solvent). To evaluate kinetic of bacterial adhesion to solvents over night grown bacteria were harvested by centrifugation $\left(7000 \mathrm{~g}, 4^{\circ} \mathrm{C}, 10 \mathrm{~min}\right.$.), then washed twice using $150 \mathrm{mM} \mathrm{NaCl}$ and a re-suspended in a $150 \mathrm{mM} \mathrm{NaCl}$ solution. The high $\mathrm{NaCl}$ concentration was used to avoid charge interference. The initial optical density $\left(\mathrm{OD}_{\mathrm{i}}\right)$ of this suspension was then adjusted to around 0.8 at $400 \mathrm{~nm}$. The suspension was divided in six $2.4 \mathrm{ml}$ samples, $0.4 \mathrm{ml}$ of a solvent was added to each of them. The samples were mixed 10, 20, 30, 40, 50 and 60 seconds with agitator type vortex (Heidolph, Schwabach, Germany). The mixtures were allowed to stand for 15 min. for complete phase separation. The aqueous phase was then removed and the final optical density $\left(O D_{f}\right)$ was measured. The microbial adhesion to each solvent was calculated as $\left(O D_{i}-O D_{f}\right) / O D_{i} \times 100$ and presented in percents. Each experiment was performed in triplicate using independently prepared cultures.

\section{Electrophoretic mobility}

After overnight growth, bacteria were harvested by centrifugation $\left(7000 \mathrm{~g}, 4^{\circ} \mathrm{C}, 10 \mathrm{~min}\right.$.), washed twice with 1.5 $\mathrm{mM} \mathrm{NaCl}$ and suspended in the same buffer at a final cell density of $10^{7} \mathrm{cfu} / \mathrm{ml}$. The $\mathrm{pH}$ of the suspension was adjusted in the range of $\mathrm{pH} 2$ to 7 , as needed, by adding nitric acid or potassium hydroxide (Sigma, Saint-Quentin, France). Electrophoretic mobility was measured with an automated zetameter (Zetaphoremètre II, CAD Instrumentations, Paris, France) using an electric field of $50 \mathrm{~V}$. Each experiment was performed in triplicate using three independent cultures.

\section{Preparation of solid supports}

The solid surfaces used in this experiment were micro cover glasses (Menzel Glass ${ }^{\circledR}$, LDS 2460, $24 \times 60$, Braunschweig, Germany) and $3 \times 1.4 \mathrm{~cm}$ coupons of polytetrafluorethylene (PTFE, Goodfellow SARL, Lille, France). Before adhesion tests, the supports were washed $15 \mathrm{~min}$. at $50^{\circ} \mathrm{C}$ with detergent RBS 35 (2\%, Société des Traitements Chimiques de Surfaces, Lambersart, France) with shaking, then rinsed five times with $50^{\circ} \mathrm{C}$ water and 
five times with Milli-Q water (Millipore, Saint-Quentinen-Yvelines France).

\section{Contact angle measurements}

The Lifshitz-van der Waals $\left(\gamma^{\mathrm{LW}}\right)$, electron-donor $(\gamma)$ and electron-acceptor $\left(\gamma^{+}\right)$surface tension components of the solid surfaces $(S)$ were determined by measuring contact angles using the expression $\cos \theta=-1+2\left(\gamma_{s}^{L W} \gamma_{L}^{L W}\right)^{1 / 2} / \gamma_{L}+2\left(\gamma_{s}^{+} \gamma_{L}^{-}\right)^{1 / 2} / \gamma_{L}+2\left(\gamma_{s}^{-} \gamma_{L}^{+}\right)^{1 / 2} / \gamma_{L}$ [6]. We measured the contact angles $(\theta)$ of glass and PTFE with three pure liquids (L), which were deionised water (Purit, Lormont, France), formamide and diiodomethane (Sigma, Saint-Quentin, France).

\section{Bacterial adhesion to solid surfaces}

Slides were incubated in $30 \mathrm{ml}$ of bacterial suspension $\left(\mathrm{O} \mathrm{D}_{600}=0.8\right)$ in 1.5 and $150 \mathrm{mM} \mathrm{NaCl}$ solution in Petri plates for 1 hour, then rinsed five times (care was taken to prevent slides from drying between washes), and colored for $15 \mathrm{~min}$. with $0.01 \%(\mathrm{w} / \mathrm{v})$ acridine orange water solution (Sigma, St. Louis, MO). Fluorescently colored cells were visualized and images captured with epifluorescence microscope (Leica DMLB, Tokyo, Japan, equipped with objective 10x). Ten images of each slide were taken and analyzed with UTHSCSA ImageTool program . Microbial adhesion was estimated as the percentage of solid surface covered by bacteria. Each value presented is the mean of at least three independent set of experiments.

\section{Statistical analysis}

Multifactor ANOVA variance analyses were performed with statistical analysis program Statgraphics Plus 4.1 (Manugistics, Rockville, MD).

\section{Authors' contributions}

OH and CLG performed MATS, adhesion to solid surfaces and electrophoretic mobility measurements and helped in draft the manuscript, VJ and MNBF participated in the design of the study and interpretation of results, GB participated in plasmid constructions, design of the study and critical reading of the manuscript, SK and RB conceived the study and drafted the manuscript. All authors read and approved the final manuscript.

\section{Acknowledgements}

We thank A. Gruss for critical reading of the manuscript, J. Tremblay for technical help, J. - C. Piard for discussions and J. Kok for providing the proteinase producing strains. $O$. Habimana is the recipient of a fellowship from LABHEALTH, the Marie Curie Contract MEST-CT-2004-5I 4428.

\section{References}

I. Costerton JW, Lewandowski Z, Caldwell DE, Korber DR, LappinScott HM: Microbial biofilms. Annu Rev Microbiol 1995, 49:7I I-745.

2. Davey ME, O'Toole G A: Microbial biofilms: from ecology to molecular genetics. Microbiol Mol Biol Rev 2000, 64:847-867.
3. Morton L. H. G. G D. L. A., Gaylarde, C. C., Surman, S. B: Consideration of some implications of the resistance of biofilms to biocides. International Biodeterioration \& Biodegradation 1998, 4I:247-259.

4. Mah TF, O'Toole GA: Mechanisms of biofilm resistance to antimicrobial agents. Trends Microbiol 200I, 9:34-39.

5. Bos R, van der Mei HC, Busscher HJ: Physico-chemistry of initial microbial adhesive interactions--its mechanisms and methods for study. FEMS Microbiol Rev 1999, 23:179-230.

6. van Oss CJ: Forces interfaciales en milieux aqueux. Paris, Masson; 1996.

7. Zottola EA, Sasahara KC: Microbial biofilms in the food processing industry--should they be a concern? Int J Food Microbiol 1994, 23:125-148.

8. Austin JW, Bergeron G: Development of bacterial biofilms in dairy processing lines. J Dairy Res 1995, 62:509-519.

9. Agarwal S, Sharma K, Swanson BG, Yuksel GU, Clark S: Nonstarter lactic acid bacteria biofilms and calcium lactate crystals in Cheddar cheese. J Dairy Sci 2006, 89: 1452-I 466.

10. Briandet R, Herry J, Bellon-Fontaine M: Determination of the van der Waals, electron donor and electron acceptor surface tension components of static Gram-positive microbial biofilms. Colloids Surf B Biointerfaces 200I, $21: 299-310$.

II. Zhao T, Doyle MP, Zhao P: Control of Listeria monocytogenes in a biofilm by competitive-exclusion microorganisms. Appl Environ Microbiol 2004, 70:3996-4003.

12. Leriche $V$, Chassaing $D$, Carpentier B: Behaviour of L. monocytogenes in an artificially made biofilm of a nisin-producing strain of Lactococcus lactis. Int J Food Microbiol I999, 5 I: 169-182.

13. Pongtharangkul T, Demirci A: Evaluation of culture medium for nisin production in a repeated-batch biofilm reactor. Biotechnol Prog 2006, 22:217-224.

14. Zhao T, Podtburg TC, Zhao P, Schmidt BE, Baker DA, Cords B, Doyle MP: Control of Listeria spp. by competitive-exclusion bacteria in floor drains of a poultry processing plant. Appl Environ Microbiol 2006, 72:3314-3320.

15. Leriche V, Carpentier B: Limitation of adhesion and growth of Listeria monocytogenes on stainless steel surfaces by Staphylococcus sciuri biofilms. J Appl Microbiol 2000, 88:594-605.

16. van Loosdrecht MC, Lyklema J, Norde W, Schraa G, Zehnder AJ: Electrophoretic mobility and hydrophobicity as a measured to predict the initial steps of bacterial adhesion. Appl Environ Microbiol 1987, 53:1898-190।.

17. van Loosdrecht MC, Lyklema J, Norde W, Schraa G, Zehnder AJ: The role of bacterial cell wall hydrophobicity in adhesion. Appl Environ Microbiol 1987, 53:1893-1897.

18. Boonaert CJ, Rouxhet PG: Surface of lactic acid bacteria: relationships between chemical composition and physicochemical properties. Appl Environ Microbiol 2000, 66:2548-2554.

19. Navarre WW, Schneewind O: Surface proteins of gram-positive bacteria and mechanisms of their targeting to the cell wall envelope. Microbiol Mol Biol Rev 1999, 63:174-229.

20. Peacock SJ, Lina G, Etienne J, Foster TJ: Staphylococcus schleiferi subsp. schleiferi expresses a fibronectin-binding protein. Infect Immun 1999, 67:4272-4275.

21. Foster TJ, McDevitt D: Surface-associated proteins of Staphylococcus aureus: their possible roles in virulence. FEMS Microbiol Lett 1994, I I 8: 199-205.

22. Godon JJ, Jury K, Shearman CA, Gasson MJ: The Lactococcus lactis sex-factor aggregation gene cluA. Mol Microbiol 1994, 1 2:655-663.

23. van der Meer JR, Polman J, Beerthuyzen MM, Siezen RJ, Kuipers OP, De Vos WM: Characterization of the Lactococcus lactis nisin A operon genes nisP, encoding a subtilisin-like serine protease involved in precursor processing, and nisR, encoding a regulatory protein involved in nisin biosynthesis. J Bacteriol 1993, 175:2578-2588.

24. Reid JR, Coolbear T: Altered Specificity of Lactococcal Proteinase $P(I)$ (Lactocepin I) in Humectant Systems Reflecting the Water Activity and Salt Content of Cheddar Cheese. Appl Environ Microbiol 1998, 64:588-593.

25. Siezen RJ: Multi-domain, cell-envelope proteinases of lactic acid bacteria. Antonie Van Leeuwenhoek 1999, 76:139-I55.

26. Mazmanian SK, Ton-That H, Schneewind O: Sortase-catalysed anchoring of surface proteins to the cell wall of Staphylococcus aureus. Mol Microbiol 200 I, 40: 1049-1057. 
27. Haandrikman AJ, Kok J, Laan H, Soemitro S, Ledeboer AM, Konings $W N$, Venema G: Identification of a gene required for maturation of an extracellular lactococcal serine proteinase. J Bacteriol | 989, | 7 |:2789-2794.

28. Ramasamy R, Yasawardena S, Zomer A, Venema G, Kok J, Leenhouts $\mathrm{K}$ : Immunogenicity of a malaria parasite antigen displayed by Lactococcus lactis in oral immunisations. Vaccine 2006, 24:3900-3908

29. Leenhouts K, Buist G, Kok J: Anchoring of proteins to lactic acid bacteria. Antonie Van Leeuwenhoek 1999, 76:367-376.

30. Bensing BA, Rubens CE, Sullam PM: Genetic loci of Streptococcus mitis that mediate binding to human platelets. Infect Immun 200I, 69:1373-1380.

31. Kok J, Buist G: Genetics of proteolysis in Lactococcus lactis. In Genetics of Lactic Acid Bacteria Volume 7. Edited by: Wood BJB, Warner PJ. New York, Kluwer Academic/Plenum Publishers; 2003:I89-223.

32. Vos P, Boerrigter IJ, Buist G, Haandrikman AJ, Nijhuis M, de Reuver MB, Siezen RJ, Venema G, de Vos WM, Kok J: Engineering of the Lactococcus lactis serine proteinase by construction of hybrid enzymes. Protein Eng 1991, 4:479-484.

33. Briandet R, Meylheuc T, Maher C, Bellon-Fontaine MN: Listeria monocytogenes Scott A: cell surface charge, hydrophobicity, and electron donor and acceptor characteristics under different environmental growth conditions. Appl Environ Microbiol 1999, 65:5328-5333.

34. Haandrikman AJ, Meesters R, Laan H, Konings WN, Kok J, Venema $\mathrm{G}$ : Processing of the lactococcal extracellular serine proteinase. Appl Environ Microbiol I991, 57:1899-1904.

35. Helinck S, Richard J, Juillard V: The effects of adding lactococcal proteinase on the growth rate of Lactococcus lactis in milk depend on the type of enzyme. Appl Environ Microbiol 1997, 63:2124-2130.

36. Exterkate FA: Structural changes and interactions involved in the $\mathrm{Ca}(2+)$-triggered stabilization of the cell-bound cell envelope proteinase in Lactococcus lactis subsp. cremoris SKI I. Appl Environ Microbiol 2000, 66:2021-2028.

37. Rijnaarts HH, Norde W, Bouwer EJ, Lyklema J, Zehnder AJ: Bacterial Adhesion under Static and Dynamic Conditions. Appl Environ Microbiol 1993, 59:3255-3265.

38. Fletcher M, Loeb GI: Influence of Substratum Characteristics on the Attachment of a Marine Pseudomonad to Solid Surfaces. Appl Environ Microbiol 1979, 37:67-72.

39. Buist G, Venema G, Kok J: Autolysis of Lactococcus lactis is influenced by proteolysis. J Bacteriol 1998, I 80:5947-5953.

40. Mercier C, Durrieu C, Briandet R, Domakova E, Tremblay J, Buist G, Kulakauskas S: Positive role of peptidoglycan breaks in lactococcal biofilm formation. Mol Microbiol 2002, 46:235-243.

4I. Ibrahim M, Briandet R, Mistou MY, Chretien A, Tremblay J, Kulakauskas S: Immobilisation des lactocoques. Lait 2004, 84: I03-I I4.

42. LaPolla RJ, Haron JA, Kelly CG, Taylor WR, Bohart C, Hendricks M, Pyati JP, Graff RT, Ma JK, Lehner T: Sequence and structural analysis of surface protein antigen I/II (SpaA) of Streptococcus sobrinus. Infect Immun 1991, 59:2677-2685.

43. McNab R, Forbes H, Handley PS, Loach DM, Tannock GW, Jenkinson HF: Cell wall-anchored CshA polypeptide ( 259 kilodaltons) in Streptococcus gordonii forms surface fibrils that confer hydrophobic and adhesive properties. I Bacteriol 1999, | 8 |:3087-3095.

44. Heilmann C, Hussain M, Peters G, Gotz F: Evidence for autolysinmediated primary attachment of Staphylococcus epidermidis to a polystyrene surface. Mol Microbiol 1997 24:1013-1024.

45. Milohanic E, Jonquieres R, Cossart P, Berche P, Gaillard JL: The autolysin Ami contributes to the adhesion of Listeria monocytogenes to eukaryotic cells via its cell wall anchor. Mol Microbiol 2001, 39: I212-1224.

46. Gasson M): Plasmid complements of Streptococcus lactis NCDO 712 and other lactic streptococci after protoplastinduced curing. J Bacteriol 1983, I 54: I-9.

47. Kok J, van Dijl JM, van der Vossen JM, Venema G: Cloning and expression of a Streptococcus cremoris proteinase in BacilIus subtilis and Streptococcus lactis. Appl Environ Microbiol 1985, 50:94-I0I.

48. Terzaghi BE, Sandine WE: Improved Medium for Lactic Streptococci and Their Bacteriophages. Appl Microbiol 1975, 29:807-8I3
49. Bellon-Fontaine MN, Rault J, van Oss C: Microbial adhesion to solvents: a novel method to determine the electron donor/ electron acceptor or Lewis acid-base properties of microbial cells. Colloids and Surfaces B: Biointerfaces 1996, 7:47-53.
Publish with Biomed Central and every scientist can read your work free of charge

"BioMed Central will be the most significant development for disseminating the results of biomedical research in our lifetime. "

Sir Paul Nurse, Cancer Research UK

Your research papers will be:

- available free of charge to the entire biomedical community

- peer reviewed and published immediately upon acceptance

- cited in PubMed and archived on PubMed Central

- yours - you keep the copyright 